\title{
Polycyclic Aromatic Hydrocarbons (PAHs) In The Upstream Rivers of Taihu Lake Basin, China: Spatial Distribution, Sources And Environmental Risk
}

\author{
Lingling Wang \\ Jiangsu Provincial Academy of Environmental Science \\ Xiaoming Ren \\ Jiangsu Provincial Academy of Environmental Science \\ Xiaoping Wang \\ Jiangsu Provincial Academy of Environmental Science \\ Perran Ye \\ Jiangsu Provincial Academy of Environmental Science
}

Fei Wang

Jiangsu Provincial Academy of Environmental Science

Jiade Cheng

Jiangsu Provincial Academy of Environmental Science

Yan Chen

Jiangsu Provincial Academy of Environmental Science

Ang Yu

Jiangsu Provincial Academy of Environmental Science

Limin Zhang

Jiangsu Provincial Academy of Environmental Science

Yang Qiu ( $\sim$ qiuyang197904@163.com )

Jiangsu Provincial Academy of Environmental Science https://orcid.org/0000-0003-3760-7554

\section{Research Article}

Keywords: Taihu Lake Basin, polycyclic aromatic hydrocarbon, sediment, source, ecological risk assessment, health risk

Posted Date: September 20th, 2021

DOI: https://doi.org/10.21203/rs.3.rs-828787/v1

License: (ㄷ) (1) This work is licensed under a Creative Commons Attribution 4.0 International License. Read Full License

Version of Record: A version of this preprint was published at Environmental Science and Pollution Research on November 23rd, 2021. See the published version at https://doi.org/10.1007/s11356-021-17598-w. 


\section{Abstract}

The polycyclic aromatic hydrocarbons (PAHs) pollution in Taihu Lake Basin has caused widespread concern. However, the spatial temporal distribution of PAHs in the upstream rivers of Taihu Lake Basin remains largely unknown. Thus, this study aims to investigate the level, spatial distribution, sources and environment risk caused by PAHs in upstream rivers of Taihu Lake Basin. The concentrations of total $16 \mathrm{PAHs}$ ( $\sum 16 \mathrm{PAHs}$ ) ranged from 188.64 to $1060.39 \mathrm{ng} / \mathrm{g}$, with an average of $472.62 \mathrm{ng} / \mathrm{g}$. Compared with low-molecular-weight (LMW) PAHs, high-molecular-weight (HMW) PAHs were more resistant to degradation and easier to accumulate in the sediment. The results of source analysis demonstrated that the PAH pollution was mainly sourced from mixture of fuel combustion and direct petroleum spillage. The ecological risk assessment showed that moderate ecological risk caused by the PAH contaminants might occur in most sample sites. The incremental lifetime cancer risk (ILCRs) ranged from $2.07 \times 10^{-4}-2.66 \times 10^{-3}$ for children and $9.66 \times 10^{-5}-1.24 \times 10^{-3}$ for adult, indicating moderate cancer risk of PAH-contaminated sediments.

\section{Introduction}

Polycyclic aromatic hydrocarbons (PAHs) are ubiquitous in various environmental medium and primarily produced by petroleum spillage and incomplete combustion of organic materials(Ravindra et al. 2008, Thompson et al. 2017). PAHs can enter the aquatic environments by atmospheric deposition, surface runoff, oil leakage, and waste water discharge(Hu et al. 2017). Due to their low water solubility, high lipid solubility and high persistence, PAHs have the propensity to adhere to sediment of water bodies, which ultimately pose considerable threats to ecosystem and human health through the biomagnify in the food chain(Geffard et al. 2003, Humans 2010, Ma et al. 2018). 16 PAHs have been identified as the priority pollutants in control by the U.S Environmental Protection Agency (U.S.EPA) (E. Manoli 2000, Wang et al. 2010), and 7 of them represent potential carcinogenicity(Zheng et al. 2016), which cause both ecological and health risks(Kim et al. 2013, Sarria-Villa et al. 2016).

Taihu Lake is the third largest freshwater lake in China, which is important for drinking water, tourism, recreation, shipping, aquaculture and industry(Qin et al. 2007). However, due to the massive discharge of industrial wastewater, the lake, especially the northern part of the lake, is faced with serious deterioration of water quality (Chen et al. 2018, Li et al. 2019, Niu et al. 2020, Tao et al. 2018, Xu et al. 2014, Zhao et al. 2017). Several studies have detected the PAHs in the northern part of Taihu Lake (Guo et al. 2012, Li et al. 2019, Qiao et al. 2006, Tang et al. 2015), indicating serious pollution in the upstream rivers. However, the occurrence, environmental risk and source of PAHs in the upstream rivers remains largely unknown. Thus, this study aims to elucidate the level, spatial distribution, source and environment risk of PAHs in upstream rivers of Taihu Lake Basin. The results will help to further understand the characteristics and risk of PAHs, and provide a valuable reference data for PAHs management in the Taihu Lake Basin.

\section{Materials And Methods}

\subsection{Sample collection}

The sediment samples (depth $0-5 \mathrm{~cm}$ ) in 18 sample sites were collected in Taihu Lake Basin, including 16 in the upstream rivers and 2 in the wastewater treatment plants (WTPs) (Fig. 1). A stainless steel grab sampler was used to collect the sediment samples, and then wrapped, stored, transported to the laboratory. Before the sample analysis, all samples were stored at $-20^{\circ} \mathrm{C}$.

\subsection{Sample extraction and cleanup}

Accelerated Solvent Extraction (ASE) in static conditions was used to extract the samples. Each sample (10g) was mixed with diatomite and milled in the disc. The samples were then transported to the extraction tank and mixed with $20 \mathrm{~mL}$ hexane and acetone (1:1, v/v) solution for $30 \mathrm{~min}$ (Belo et al. 2017, De Nicola et al. 2005, Liu et al. 2017). The extracts were 
collected into a round-bottomed flask and dehydrated by filtering through anhydrous sodium sulfate(Bortey-Sam et al. 2014), which were then concentrated, solvent-exchanged with n-hexane and further concentrated to approximately $2 \mathrm{ml}$ under a gentle N2 stream. Clean-up solid-phase cartridges filled with silica and copper powder were used to fractionate the PAH extracts. Before use, the solid-phase cartridge was successively eluted with $4 \mathrm{ml}$ dichloromethane and $5 \mathrm{ml}$ hexane. The extracts were eluted with $2 \mathrm{~mL}$ hexane for three times and $10 \mathrm{~mL}$ dichloromethane/hexane (1:9, v/v). The eluate was reconcentrated to $1 \mathrm{ml}$ under a gentle $\mathrm{N} 2$ stream. Known quantities of an internal standard (p-dichlorobenzene_d $\mathrm{d}_{4}$, naphthalene_d $d_{8}$, phenanthrene_d $d_{10}$, chrysene_d $d_{12}$ and perylene_d $d_{12}$ ) were added to the samples prior to instrumental analysis.

\subsection{Chemical analysis}

Gas chromatography/mass spectrometry (GC-MS, Agilent 9000/5977B) equipped with a fused silica capillary column was used to quantify the concentration of $16 \mathrm{PAHs}$. Helium was used as carrier gas with flow rate of $1 \mathrm{ml} / \mathrm{min}$. Samples $(1 \mu \mathrm{l})$ were injected with an auto-sampler for analysis. The initial oven temperature programmed at $40^{\circ} \mathrm{C}$ for 4 min, increased to $80^{\circ} \mathrm{C}$ at a rate of $10^{\circ} \mathrm{C} / \mathrm{min}$, which was maintained for $2 \mathrm{~min}$, and then increased at $5^{\circ} \mathrm{C} / \mathrm{min}$ to $200^{\circ} \mathrm{C}$, maintained for 1 min, and finally heated to $280^{\circ} \mathrm{C}$ at a rate of $10^{\circ} \mathrm{C} / \mathrm{min}$, maintained for $10 \mathrm{~min}$. The injection port temperature was set at $280^{\circ} \mathrm{C} .16$ USEPA priority PAH compounds including naphthalene (Nap), acenaphthylene (Acy), acenaphthene (Ace), fluorine (Fluo), phenanthrene (Phe), anthracene(Ant), fluoranthene (Flua), pyrene (Pyr), benz[a]anthracene (BaA), chrysene (Chr), benzo[b]fluoranthene $(\mathrm{BbF})$, benzo[k]fluoranthene $(\mathrm{BkF})$, benzo[a]pyrene $(\mathrm{BaP})$, indeno[1,2,3-cd]pyrene $(\mathrm{InP})$, dibenz[a,h]anthracene (DbA) and benzo[g,h,i]perylene (BgP) were analyzed(Lin et al. 2018).

\subsection{Quality assurance and quality control}

Procedural blanks, method blanks, matrix spikes, and sample duplicates were routinely processed to ensure data quality ( $\mathrm{Li}$ et al. 2015). Quantitation was performed using an internal standard calibration method, the correlation coefficients $\left(r^{2}\right)$ of the calibration curves were all higher than 0.999. Recovery rate for the different PAHs ranged from $63 \%$ to $97 \%$ in sediment samples. The limit of detection (LOD) were ranged from 0.08 to $0.17 \mathrm{mg} / \mathrm{kg}$ dry weight for PAHs. Method blank operation showed no PAH was observed from the reagents and procedures.

\subsection{Toxicity and risk assessment}

\subsubsection{Ecological risk assessment}

The sediment quality guidelines (SQGs) were applied to assess the ecological risk of PAHs in the sediment in this study. The concentration of PAHs were compared with concentration limits of SQGs. Two sets of SQGs, including (a) Effect range low (ERL)/ Effect range median (ERM) and (b) Threshold effect level (TEL)/ Probable effect level (PEL)(MacDonald et al. 2004, McCready et al. 2006). The PAH concentration were classified into three different ranges: adverse ecological risk rarely occurred (<ERL/TEL), occasionally occurred ( $\geq E R L / T E L$ and $<$ ERM/PEL), and frequently occurred ( $\geq E R M / P E L)(L o n g$ 1995, Macdonald et al. 1996).

In addition, mean PEL quotient (mean PEL-Q) was used to estimate the probable ecological risk of multiple contaminants(Long \&MacDonald 1998). The mean PEL-Q equations is as follows:

Mean PEL $-\mathrm{Q}=\frac{1}{\mathrm{n}} \sum_{1}^{\mathrm{n}} \frac{\mathrm{C}_{\mathrm{i}}}{\mathrm{PEL}_{\mathrm{i}}}$

in the formula, $\mathrm{C}_{i}$ is the concentration of the PAH $i$ in sediment; $P E L_{i}$ is the probable ecological risk of the PAH $i, n$ is the number of PAHs with available sediment quality guideline. The PEL-Q values were divided into three categories: (1) PEL-Q $\leq$ 0.1 , indicate low ecological risk. (2) $0.1<P E L-Q \leq 1.0$, indicate moderate ecological risk. (3) $P E L-Q>1.0$, indicate high ecological risk(MacDonald et al. 2004).

\subsubsection{Toxicity and carcinogenic risk assessment}


7 PAHs (BaA, Chr, BbF, BkF, BaP, DaA, and InP) were identified as carcinogenic compounds. Toxic equivalent factors (TEFs) were taken as the reference chemical to compute the toxic equivalent concentrations $\left(T_{E Q_{B a P}}\right)$ of $P A H s$ in the sediment. The $\mathrm{TEQ}_{\mathrm{BaP}}$ of each PAH is the PAH concentration multiplied by its TEF value(Soltani et al. 2015, Tian et al. 2013). The total $\mathrm{TEQ}_{\mathrm{BaP}}$ of 16 PAHs $\left(\mathrm{TEQ}_{\sum 16 \mathrm{PAHs}}\right.$ ) and 7 carcinogenic $\mathrm{PAHs}\left(\mathrm{TEQ}_{\sum 7 \mathrm{PAHs}}\right)$ were both calculated according to the following equation:

$\mathrm{TEQ}_{\mathrm{i}}=\mathrm{C}_{\mathrm{i}} \times \mathrm{TEF}_{\mathrm{i}}$ and $\mathrm{TEQ}_{\mathrm{PAH}}=\sum_{i=1}^{n} C_{i} \times T E F_{i}$

where $\mathrm{C}_{i}$ is the concentration of single PAH $\mathrm{i} \mathrm{TEF}_{\mathrm{i}}$ refers to TEF of this compound, the TEF values of PAHs were shown in Table 2. $\mathrm{TEQ}_{i}$ is the toxic equivalent of the PAH $\mathrm{i}$ and $\mathrm{TEQ}_{\mathrm{PAH}}$ stands for total toxic concentration of PAHs. 
Table 2

Descriptive statistics of PAHs in river sediments $(\mathrm{ng} / \mathrm{g})$

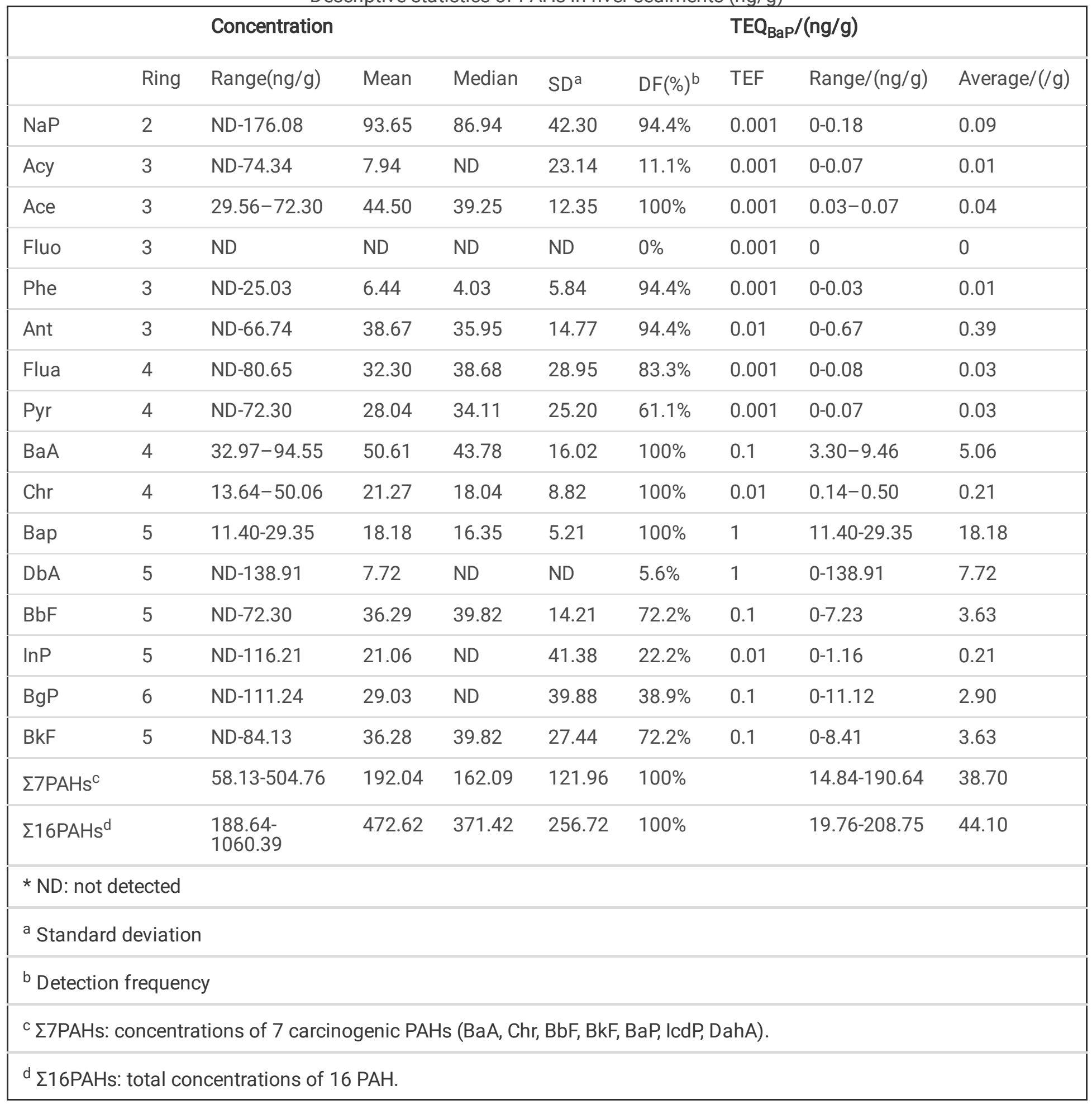

In general, oral ingestion and dermal absoption are the two main ways of human exposure to PAHs in sediments. To assess the potential carcinogenic risk of PAHs in the sediment, the incremental lifetime cancer risk (ILCR) were estimated based on the US EPA standard models. The ILCR through oral ingestion and dermal absorption pathways were estimated using following equations (Soltani et al. 2015, Wang et al. 2015):

$\mathrm{ILCR}_{\text {ing }}=\frac{\mathrm{C}_{\text {sed }} \times \mathrm{IR} \times \mathrm{EF} \times \mathrm{ED} \times \mathrm{CF}}{\mathrm{BW} \times \mathrm{AT}} \times S F_{\text {ing }}$
$\mathrm{ILCR}_{\mathrm{der}}=\frac{\mathrm{C}_{\text {sed }} \times \mathrm{SA} \times \mathrm{AF} \times \mathrm{ABS} \times \mathrm{EF} \times \mathrm{ED} \times \mathrm{CF}}{\mathrm{BW} \times \mathrm{AT}} \times \frac{S F_{\text {ing }}}{A B S_{G I}}$ 
$\mathrm{ILCRs}_{\mathrm{s}}=\sum \mathrm{ILCR}_{\text {ing }}+\mathrm{ILCR}_{\text {der }}(5)$

Where, $\mathrm{C}_{\text {sed }}$ is the toxic concentration of 7 carcinogenic PAHs in the sediment (ng/g). (Keshavarzifard et al. 2017). Other parameters referred in the model for children and adults are based on the Risk Assessment Guidance of US EPA and related publications (Table 1). According to the guidelines recommended by the US EPA, the value of ILCRs less than or equal to $10^{-}$ 6 , between $10^{-6}$ and $10^{-4}$ and exceeding $10^{-4}$ signify acceptable level, potential moderate risk and potentially high risk, respectively(Liang et al. 2019, Soltani et al. 2015, USEPA 2004).

Table 1

Parameters used in the incremental lifetime cancer risk assessment

\begin{tabular}{|c|c|c|c|c|}
\hline Exposure variables & Unit & Child & Adult & Reference \\
\hline Ingestion rate(IR) & $\mathrm{mg} \mathrm{day}^{-1}$ & 200 & 100 & (Soltani et al. 2015) \\
\hline Exposure frequency(EF) & day year-1 & 350 & 350 & (USEPA 2004) \\
\hline Exposure duration(ED) & year & 6 & 30 & (USEPA 2004) \\
\hline Conversion factor & $\mathrm{g} \mathrm{ng}^{-1}$ & $10^{-6}$ & $10^{-6}$ & (USEPA 2004) \\
\hline Body weight(BW) & $\mathrm{kg}$ & 15 & 70 & (USEPA 2004) \\
\hline Average life span(AT) & day & 25550 & 25550 & (USEPA 2004) \\
\hline Oral slope factor of Bap(SF $\left.F_{\text {ing }}\right)$ & $\left(\mathrm{mg} \mathrm{kg}^{-1} \mathrm{~d}^{-1}\right)^{-1}$ & 7.3 & 7.3 & (Wang et al. 2015) \\
\hline Dermal exposure area(SA) & $\mathrm{cm}^{2}$ day $^{-1}$ & 2800 & 5700 & (USEPA 2004) \\
\hline Dermal adherence factor(AF) & $\mathrm{cm}^{2} \mathrm{mg}^{-1}$ & 0.2 & 0.07 & (USEPA 2004) \\
\hline Dermal absorption(ABS) & unitless & 0.13 & 0.13 & (Wang et al. 2015) \\
\hline Gastrointestinal absorption $\left(\mathrm{ABS}_{\mathrm{GI}}\right)$ & unitless & 1 & 1 & (USEPA 2004) \\
\hline
\end{tabular}

\subsection{Statistical analysis}

R software 4.0.0 and IBM SPSS22.0 for Windows were used for statistical analyses. The spatial distributions of PAHs in the sediment were analyzed using ArcGIS 10.2 software. PCA was performed to analyze the source distributions of different PAHs. The data for PAHs were standardized to unit variance prior to PCA analysis(Bemanikharanagh et al. 2017).

\section{Results And Discussion}

\subsection{Level of PAHs in the sediment}

The PAH concentrations of 18 sediments samples are presented in Table 2. The concentrations of total 16 PAHs ( $(16 \mathrm{PAHs})$ ranged from 188.64 to $1060.39 \mathrm{ng} / \mathrm{g}$, with an average of of $472.62 \mathrm{ng} / \mathrm{g}$. The PAH concentration was similar with the studies conducted by Yuan Zhang(Zhang et al. 2012) and Bingli Lei(Lei et al. 2014), but showed a decrease than the level reported by Yuqiang Tao(Tao et al. 2010). The concentrations of total 7 carcinogenic PAHs ( $27 P A H s)$ ranged from 58.13 to $504.76 \mathrm{ng} / \mathrm{g}$, with an average of $192.04 \mathrm{ng} / \mathrm{g}$, which account for $40.63 \%$ of the $\Sigma 16$ PAHs. Among 16 PAHs, Nap was the main pollutant with mean concentration of $93.65 \mathrm{ng} / \mathrm{g}$, whereas the concentration of Fluo, Acy and DbA were below the detection limit in almost samples.

\subsection{Spatial distributions of PAHs}

Figure 1 depicted the spatial distribution of $\Sigma 16 \mathrm{PAHs}$ in the sampling sites. The highest concentration of $\Sigma 16 \mathrm{PAHs}$ (1060.39 $\mathrm{ng} / \mathrm{g}$ ) was detected at WTP2, followed by $912.15 \mathrm{ng} / \mathrm{g}$ at S12, $850.68 \mathrm{ng} / \mathrm{g}$ at S13, $749.74 \mathrm{ng} / \mathrm{g}$ at S7 and $586.84 \mathrm{ng} / \mathrm{g}$ at 
S16. The lowest concentration of $516 \mathrm{PAHs}(188.64 \mathrm{ng} / \mathrm{g})$ was observed at S6 in the Yongan river, one of the upstream rivers.

The WTP2 is a wastewater treatment plant of Yixing city nearby chemical industrial park, which is responsible for treating surrounding chemical wastewater, suggesting that the highest level of PAHs at site WTP2 might be associated with chemical plant emission. Sites S12, S13 and S16 are located in the lake estuary, where many chemical plants were concentrated, which may attribute to the chemical industrial activities. S7 is located at the Beijing-Hangzhou Canal of Changzhou, which is near the printing and dyeing industries, suggesting that wastewater from printing and dyeing operations might be the main source of PAH pollution. (Liu et al. 2016, Wang et al. 2018). The geographic distribution of PAHs showed that $\Sigma 16 \mathrm{PAH}$ concentrations in the downstream rivers were higher than those in adjacent upstream rivers, which could be associated with domestic industrial wastewater and adhesion of upstream PAH pollution in sediment(Wang et al. 2018).

The composition patterns of the PAHs by ring size in the 18 samples were depicted in Fig. 2. The two-ring PAHs (Nap) accounted for $0-43.28 \%$ of the total PAH content, three-ring PAHs 14.17-31.88\% (Acy, Ace, Fluo, Phe, Ant), four-ring PAHs 15.87-39.08\% (Flua, Pyr, BaA, Chr), five-ring PAHs 4.89-39.30\% (BbF, BkF, BaP, DbA), and six-ring PAHs 0-22.73\% (InP, BgP). (Lin et al. 2018). Except for S4, S5, S6, S10 and S11, high- molecular- weight (HMW) PAHs (4-6 rings) were the predominant compounds in most sample sites (51.71\% 72.29\%). Indeed, due to the high water solubility and benthic recycling in aquatic environment, low- molecular- weight (LMW) PAHs (2-3 rings) were more likely to dissolve and degrade, while HMW PAHs were more resistant to degradation and easier to accumulate in the sediment(Liu et al. 2015, Montuori et al. 2016). In general, the composition of PAHs in the sediments is dominated by high rings, indicating that the combustion at high temperature is the major source of PAH pollution in sediment.

\subsection{Source identification}

\subsubsection{Diagnostic ratio charts}

Based on the distribution levels, the diagnostic ratios of Flua / (Flua + Pyr), Ant / (Ant + Phe), BaA / (BaA + Chr), and InP / $(\mathrm{InP}+\mathrm{BgP})$ were used to identify the possible sources(Yunker MB 2002). The results of diagnostic ratio for the sampling sites were shown in Fig. 3. In this study, ratio of Ant / (Ant + Phe) $>0.1$ was found at most of the sample sites except S6, suggesting that the pollution of PAHs was attributed to combustion origin. Sample sites with Flua / (Flua + Pyr) $<0.4$ accounted for $44.4 \%$, and sites with $>0.5$ accounted for $55.6 \%$, which indicated that PAH pollution were mainly from source of direct petroleum spillage and combustion of biomass and coal. And similarly, the $\mathrm{BaA} /(\mathrm{BaA}+\mathrm{Chr})$ of all of the samples were $>0.35$ in this study, indicating the source of biomass and coal combustion. The ratio of $\operatorname{InP} /(\operatorname{InP}+\mathrm{BgP})$ were $<0.2 \mathrm{at}$ $77.8 \%$ of the sample sites, and only $22.2 \%$ of the sites were $>0.5$, indicating the direct petroleum spillage pollution(Bemanikharanagh et al. 2017, Bortey-Sam et al. 2014, Yunker MB 2002). Therefore, these results showed that the PAH pollution was mainly sourced from and fuel combustion direct and petroleum spillage.

\subsubsection{Principal component analysis (PCA)}

PCA was applied to further explore the PAH sources in this study(Bemanikharanagh et al. 2017, Lin et al. 2018, Zheng et al. 2016). Researches show that PAHs with LMW are abundant in petrogenic and low-temperature pyrolytic sources (e.g., petroleum spillage and incomplete combustion), while those with HMW are abundant in compounds from pyrolytic sources(Li et al. 2015). Flua, Phe, Ant, Pyr usually imply coal combustion. Ace and Acy are the foremost product of coke burning. $\mathrm{BaA}$, Chr and $\mathrm{BaP}$ are regarded as typical pollutants of biomass and coal combustion. BkF and BbF are typical pollutant of diesel emissions, and InP, BgP and DbA are typical markers of traffic emission(Kannan et al. 2005, Liu et al. 2017, Liu et al. 2016).

Barttlet's sphericity test was used to verify if the PCA was applicable in this study, and the $P$-value was $<0.01$, indicating the applicability of PCA here (Zheng et al. 2016). The factor loadings for PAH concentration by variamax rotation were shown in Table 3. Two components (PC1 and PC2) were extracted from sediment data responsible for $81.88 \%$ of the total variation of 
PAHs. The PC1 explained $71.87 \%$ of the total variance, which was highly loaded with BaA, Chr, Ant, Ace and Phe and relatively highly loaded of Flua, $\mathrm{Pyr}, \mathrm{BbF}, \mathrm{BaP}$ and $\mathrm{BkF}$, which suggest that the $\mathrm{PAH}$ pollution were mainly from the pretroleum spillage and incomplete combustion of coal, coke and biomass, while traffic emission (e.g. gasoline and diesel exhaust) is also an an important factor for PAH pollution(Zheng et al. 2016). PC2 account for $10.01 \%$ of the total variance, and InP and $\mathrm{BgP}$ account for high loadings, indicating that traffic emission was predominant in PC2, such as gasoline combustion and diesel combustion (Fig.S1).

Table 3

Factor loadings for PAHs concentritions with varimax rotation

\begin{tabular}{|llll|}
\hline PAHs & Ring & \multicolumn{2}{l|}{ Principal component } \\
\cline { 2 - 4 } & & PC1 & PC2 \\
\hline NaP & 2 & 0.59 & 0.51 \\
\hline Ace & 3 & 0.93 & 0.25 \\
\hline Phe & 3 & 0.87 & 0.23 \\
\hline Ant & 3 & 0.87 & 0.19 \\
\hline Flua & 4 & 0.79 & 0.32 \\
\hline Pyr & 4 & 0.82 & 0.33 \\
\hline BaA & 4 & 0.95 & 0.23 \\
\hline Chr & 4 & 0.94 & 0.18 \\
\hline Bap & 5 & 0.75 & 0.56 \\
\hline BbF & 5 & 0.75 & 0.46 \\
\hline InP & 5 & 0.06 & 0.96 \\
\hline BgP & 6 & 0.37 & 0.77 \\
\hline BkF & 5 & 0.73 & 0.52 \\
\hline Variance(\%) & & 71.87 & 10.01 \\
\hline Cumulative(\%) & & 71.87 & 81.88 \\
\hline
\end{tabular}

Therefore, these findings further confirmed that PAH pollution were mainly sourced from mixture of petroleum spillage and fuel combustion, such as coal, coke, biomass, gasoline and diesel. which may be associated with intensive traffic (e.g. shipping), discharge of urban sewage and industrial wastewater(Li et al. 2015).

\subsection{Risk assessment}

\subsubsection{Ecological risk assessment}

Table 4 shows the results of ecological risk assessment in sediment, and classifies the sample sites into three different ranges: ecological risk rarely occurred ( $<E R L / T E L)$, occasionally occurred ( $\geq E R L / T E L$ and $<E R M / P E L)$, and frequently occurred ( $\geq E R M / P E L)$. The results of SQGs showed that the concentrations were below than their respective ERM and PEL values, except for compound DbA in sample WTP2. The concentration of Ace at all of the sample sites were between $\mathrm{ERL} / \mathrm{TEL}$ and ERM/PEL, indicating that the ecological risk caused by Ace may occur occasionally at all sites. The BaA and $\mathrm{BaP}$ concentrations were at levels where ecological risk may occur occasionally ( $\geq T E L$ and $<\mathrm{PEL}$ ). Meanwhile, the concentration of Acy, Ant and Pyr at few sites were between the TEL and PEL level. The Nap concentration was below the ERL at most site, while TEL level was exceeded at most sites. In addition, the concentrations of Phe and Flua were lower 
than the ERL level at most of the sites. Therefore, these findings suggest that the pollution of Ace, BaA, BaP, Acy, Ant and Pyr may cause potential ecological risk occasionally at some sites. The mean PEL-Q values ranged from 0.09 to 0.29. Most of the sample sites had mean PEL-Q exceeded 0.1 but lower than $1.0(<P E L-Q \leq 1.0)$ and only two sites had mean PEL-Q < 0.1(S1 and WTP1), indicating that PAH contaminants may cause moderate ecological risk in most sample sites (Fig.S2).

Table 4

The summary of SQGs on PAHs in Taihu Lake.

\begin{tabular}{|lllllllllll|}
\hline \multicolumn{1}{|c}{ Number of sampling sites } & \multicolumn{5}{c|}{ Number of sampling sites } \\
\hline PAHs & ERL & ERM & $<$ ERL & (ERL,ERM) & $>$ ERM & TEL & PEL & $<$ TEL & $($ TEL,PEL) & $>$ PEL \\
\hline NaP & 160 & 2100 & 17 & 1 & - & 34.6 & 391 & 2 & 16 & - \\
\hline Acy & 44 & 640 & 16 & 2 & - & 5.87 & 128 & 16 & 2 & - \\
\hline Ace & 16 & 500 & 0 & 18 & - & 6.71 & 88.9 & - & 18 & - \\
\hline Fluo & 19 & 540 & - & - & - & 21.2 & 144 & - & - & - \\
\hline Phe & 240 & 1500 & 18 & - & - & 41.9 & 515 & 18 & - & - \\
\hline Ant & 85.3 & 1100 & 18 & - & - & 46.9 & 245 & 13 & 5 & - \\
\hline Flua & 600 & 5100 & 18 & - & - & 111 & 2355 & 18 & - & - \\
\hline Pyr & 665 & 2600 & 18 & - & - & 53 & 875 & 15 & 3 & - \\
\hline BaA & 261 & 1600 & 18 & - & - & 31.7 & 385 & - & 18 & - \\
\hline Chr & 384 & 2800 & 18 & - & - & 57.1 & 862 & 18 & - & - \\
\hline Bap & 430 & 1600 & 18 & - & - & 31.9 & 782 & - & 18 & - \\
\hline DbA & 63.4 & 260 & 17 & - & 1 & 6.22 & 135 & 17 & - & 1 \\
\hline
\end{tabular}

\subsubsection{Toxicity and health risk assessment}

The TEF of BaP were used to evaluate $T E Q_{B a P}$ of $P A H$ compounds. The TEF value of $P A H$ compounds and total their $T E Q_{B a P}$ concentrations were shown in Table 1. In the areas, the $\mathrm{TEQ}_{\sum 16 \mathrm{PAH}}$ values ranged from 19.76 to $208.75 \mathrm{ng} / \mathrm{g}$, with mean of $44.10 \mathrm{ng} / \mathrm{g}$. The site WTP2 has the highest TEQ value, followed by S13, S12 and S16. The TEQ ${ }_{\sum P A H}$ values ranged from 14.84 to $190.64 \mathrm{ng} / \mathrm{g}$, with mean of $38.70 \mathrm{ng} / \mathrm{g}$, accounting for $87 \%$ of the $\mathrm{TEQ}_{\sum 16 \mathrm{PAH}}$, suggesting that the $7 \mathrm{PAHs}$ were major carcinogenic contributors.

The results of carcinogenic risk of seven carcinogenic PAHs were shown in Fig. 4. In this study, the ILCRs ranged from 2.07 $\times 10^{-4}-2.66 \times 10^{-3}$ for children and $9.66 \times 10^{-5}-1.24 \times 10^{-3}$ for adult, which is higher than the baseline of acceptable risk. The highest risk was found in site WTP2, and followed by S13, S12 and S15, which is consistent with the spatial distributions of PAHs in sediment. Therefore, the results revealed that the PAH-contaminated sediments at most of the sites posed a potential moderate cancer risk to human health via both ingestion and dermal contact pathways.

\section{Conclusion}

The levels, spatial distributions, sources, environmental risks of PAHs in sediment from the upstream rivers of Taihu Lake Basin were analyzed. The concentrations of $\Sigma 16$ PAHs varied from 188.64 to $1060.39 \mathrm{ng} / \mathrm{g}$, with mean of $472.62 \mathrm{ng} / \mathrm{g}$. The result of spatial distribution showed that PAH concentrations in the lake estuary were higher than those in upstream rivers, including S12, S13, S16 and S15. The source identification revealed that PAH pollution were mainly sourced from mixed source of fuel combustion and petroleum spillage. Ecological risk assessment showed that moderate ecological risk caused 
by PAH contaminants may occur in most sample sites, and Ace, BaA, BaP, Acy, Ant and Pyr were likely to cause adverse biological effects occasionally in some sites. The PAH-contaminated sediments at most of the sites may cause a moderate potential cancer risk to human health via both ingestion and dermal contact pathways.

\section{Declarations}

Ethics approval and consent to participate: Not applicable.

Consent for publication: Not applicable.

Availability of data and materials: All data generated or analyzed during this study are included in this published article.

Competing interests: The authors declare that they have no competing interests.

Funding: This research was financially supported by the Provincial Special Fund for Water Pollution Control in Lake Taihu (TH2018404).

Authors' contributions: Lingling Wang was responsible for data analysis and manuscript writing; Xiaoming Ren was responsible for the design of research methods; Xiaoping Wang was responsible for Instrument calibration; Perran Ye, Fei Wang, Jiade Cheng and Yan Chen all participated in the sampling work; Limin Zhang and Ang Yu took charge of the sample analysis; Yang Qiu took charge of review and editing.

Acknowledgement: This research was financially supported by the Provincial Special Fund for Water Pollution Control in Lake Taihu (TH2018404).

\section{References}

1. Belo RFC, Figueiredo JP, Nunes CM, Pissinatti R, Souza SVC, Junqueira RG (2017): Accelerated solvent extraction method for the quantification of polycyclic aromatic hydrocarbons in cocoa beans by gas chromatography-mass spectrometry. Journal of chromatography. B, Analytical technologies in the biomedical and life sciences 1053, 87-100

2. Bemanikharanagh A, Bakhtiari AR, Mohammadi J, Taghizadeh-Mehrjardi R (2017): Characterization and ecological risk of polycyclic aromatic hydrocarbons (PAHs) and $n$-alkanes in sediments of Shadegan international wetland, the Persian Gulf. Marine Pollution Bulletin 124, 155-170

3. Bortey-Sam N, Ikenaka Y, Nakayama SMM, Akoto O, Yohannes YB, Baidoo E, Mizukawa H, Ishizuka M (2014): Occurrence, distribution, sources and toxic potential of polycyclic aromatic hydrocarbons (PAHs) in surface soils from the Kumasi Metropolis, Ghana. The Science of the total environment 496, 471-478

4. Chen M, Wang Q, Shan G, Zhu L, Yang L, Liu M (2018): Occurrence, partitioning and bioaccumulation of emerging and legacy per- and polyfluoroalkyl substances in Taihu Lake, China. The Science of the total environment 634, 251-259

5. De Nicola F, Maisto G, Prati MV, Alfani A (2005): Temporal variations in PAH concentrations in Quercus ilex L. (holm oak) leaves in an urban area. Chemosphere 61, 432-40

6. E. Manoli CS, I. Konstantinou , T. Albanis (2000): Polycyclic aromatic hydrocarbons in the bulk precipitation and surface waters of Northern Greece. Chemosphere 41, 11

7. Geffard O, Geffard A, His E, Budzinski H (2003): Assessment of the bioavailability and toxicity of sediment-associated polycyclic aromatic hydrocarbons and heavy metals applied to Crassostrea gigas embryos and larvae. Mar Pollut Bull $46,481-90$

8. Guo G, Wu F, He H, Zhang R, Feng C, Li H, Chang M (2012): Characterizing ecological risk for polycyclic aromatic hydrocarbons in water from Lake Taihu, China. Environmental monitoring and assessment 184, 6815-25 
9. Hu J, Liu C, Guo Q, Yang J, Okoli CP, Lang Y, Zhao Z, Li S, Liu B, Song G (2017): Characteristics, source, and potential ecological risk assessment of polycyclic aromatic hydrocarbons (PAHs) in the Songhua River Basin, Northeast China. Environmental science and pollution research international 24, 17090-17102

10. Humans IWGotEoCRt (2010): Some non-heterocyclic polycyclic aromatic hydrocarbons and some related exposures. IARC monographs on the evaluation of carcinogenic risks to humans 92, 1-853

11. Kannan K, Johnson-Restrepo B, Yohn SS, Giesy JP, Long DT (2005): Spatial and temporal distribution of polycyclic aromatic hydrocarbons in sediments from Michigan inland lakes. Environmental science \& technology 39, 4700-6

12. Keshavarzifard M, Zakaria MP, Sharifi R (2017): Ecotoxicological and Health Risk Assessment of Polycyclic Aromatic Hydrocarbons (PAHs) in Short-Neck Clam (Paphia undulata) and Contaminated Sediments in Malacca Strait, Malaysia. Archives of environmental contamination and toxicology 73, 474-487

13. Kim KH, Jahan SA, Kabir E, Brown RJ (2013): A review of airborne polycyclic aromatic hydrocarbons (PAHs) and their human health effects. Environment international 60, 71-80

14. Lei B, Kang J, Wang X, Yu Y, Zhang X, Wen Y, Wang Y (2014): The levels of PAHs and aryl hydrocarbon receptor effects in sediments of Taihu Lake, China. Environmental science and pollution research international 21, 6547-57

15. Li A, Beek TA, Schubert M, Yu Z, Schiedek T, Schuth C (2019): Sedimentary archive of Polycyclic Aromatic Hydrocarbons and perylene sources in the northern part of Taihu Lake, China. Environmental pollution 246, 198-206

16. Li P, Cao J, Diao X, Wang B, Zhou H, Han Q, Zheng P, Li Y (2015): Spatial distribution, sources and ecological risk assessment of polycyclic aromatic hydrocarbons in surface seawater from Yangpu Bay, China. Marine Pollution Bulletin 93, 53-60

17. Liang M, Liang H, Rao Z, Hong X (2019): Characterization of polycyclic aromatic hydrocarbons in urban-rural integration area soil, North China: Spatial distribution, sources and potential human health risk assessment. Chemosphere 234, 875-884

18. Lin F, Han B, Ding Y, Li Q, Gao W, Zheng L (2018): Distribution characteristics, sources, and ecological risk assessment of polycyclic aromatic hydrocarbons in sediments from the Qinhuangdao coastal wetland, China. Marine Pollution Bulletin 127, 788-793

19. Liu N, Li X, Zhang D, Liu Q, Xiang L, Liu K, Yan D, Li Y (2017): Distribution, sources, and ecological risk assessment of polycyclic aromatic hydrocarbons in surface sediments from the Nantong Coast, China. Mar Pollut Bull 114, 571-576

20. Liu S, Liu X, Liu M, Yang B, Cheng L, Li Y, Qadeer A (2016): Levels, sources and risk assessment of PAHs in multi-phases from urbanized river network system in Shanghai. Environmental pollution 219, 555-567

21. Liu Z, He L, Lu Y, Su J, Song H, Zeng X, Yu Z (2015): Distribution, source, and ecological risk assessment of polycyclic aromatic hydrocarbons (PAHs) in surface sediments from the Hun River, northeast China. Environmental monitoring and assessment 187, 290

22. Long ER, MacDonald DD (1998): Recommended Uses of Empirically Derived, Sediment Quality Guidelines for Marine and Estuarine Ecosystems. Human and Ecological Risk Assessment: An International Journal 4, 1019-1039

23. Long ER, Macdonald, D.D., Smith, S.L. (1995): Incidence of adverse biological effects within ranges of chemical concentrations in marine and estuarine sediments. Environmental Management 19, 5

24. Ma X, Han X, Jiang Q, Huang C, Huang T, Yang H, Yao L (2018): Historical Records and Source Apportionment of Polycyclic Aromatic Hydrocarbons Over the Past 100 Years in Dianchi Lake, a Plateau Lake in Southwest China. Archives of environmental contamination and toxicology 75, 187-198

25. Macdonald DD, Carr RS, Calder FD, Long ER, Ingersoll CG (1996): Development and evaluation of sediment quality guidelines for Florida coastal waters. Ecotoxicology 5, 253-78

26. MacDonald DD, Carr RS, Eckenrod D, Greening H, Grabe S, Ingersoll CG, Janicki S, Janicki T, Lindskoog RA, Long ER, Pribble R, Sloane G, Smorong DE (2004): Development, evaluation, and application of sediment quality targets for 
assessing and managing contaminated sediments in Tampa Bay, Florida. Archives of environmental contamination and toxicology $46,147-61$

27. McCready S, Birch GF, Long ER (2006): Metallic and organic contaminants in sediments of Sydney Harbour, Australia and vicinity- a chemical dataset for evaluating sediment quality guidelines. Environment international 32, 455-65

28. Montuori P, Aurino S, Garzonio F, Sarnacchiaro P, Nardone A, Triassi M (2016): Distribution, sources and ecological risk assessment of polycyclic aromatic hydrocarbons in water and sediments from Tiber River and estuary, Italy. The Science of the total environment 566-567, 1254-1267

29. Niu Y, Jiang X, Wang K, Xia J, Jiao W, Niu Y, Yu H (2020): Meta analysis of heavy metal pollution and sources in surface sediments of Lake Taihu, China. The Science of the total environment 700, 134509

30. Qiao M, Wang C, Huang S, Wang D, Wang Z (2006): Composition, sources, and potential toxicological significance of PAHs in the surface sediments of the Meiliang Bay, Taihu Lake, China. Environment international 32, 28-33

31. Qin B, Xu P, Wu Q, Luo L, Zhang Y (2007): Environmental issues of Lake Taihu, China. Hydrobiologia 581, 3-14

32. Ravindra K, Sokhi R, Vangrieken R (2008): Atmospheric polycyclic aromatic hydrocarbons: Source attribution, emission factors and regulation. Atmospheric Environment 42, 2895-2921

33. Sarria-Villa R, Ocampo-Duque W, Paez M, Schuhmacher M (2016): Presence of PAHs in water and sediments of the Colombian Cauca River during heavy rain episodes, and implications for risk assessment. The Science of the total environment 540, 455-65

34. Soltani N, Keshavarzi B, Moore F, Tavakol T, Lahijanzadeh AR, Jaafarzadeh N, Kermani M (2015): Ecological and human health hazards of heavy metals and polycyclic aromatic hydrocarbons (PAHs) in road dust of Isfahan metropolis, Iran. The Science of the total environment $505,712-23$

35. Tang Z, Guo J, Liao H, Zhao X, Wu F, Zhu Y, Zhang L, Giesy JP (2015): Spatial and temporal distribution and sources of polycyclic aromatic hydrocarbons in sediments of Taihu Lake, eastern China. Environmental science and pollution research international 22, 5350-8

36. Tao Y, Yao S, Xue B, Deng J, Wang X, Feng M, Hu W (2010): Polycyclic aromatic hydrocarbons in surface sediments from drinking water sources of Taihu Lake, China: sources, partitioning and toxicological risk. Journal of environmental monitoring : JEM 12, 2282-9

37. Tao Y, Dan D, Kun L, Chengda H, Haibing C, Guo F, Qiujin X, Fuhong S, Fengchang W (2018): delta(15)N and nutrient stoichiometry of water, aquatic organisms and environmental implications in Taihu lake, China. Environmental pollution 237, 166-173

38. Thompson KL, Picard CR, Chan HM (2017): Polycyclic aromatic hydrocarbons (PAHs) in traditionally harvested bivalves in northern British Columbia, Canada. Mar Pollut Bull 121, 390-399

39. Tian YZ, Li WH, Shi GL, Feng YC, Wang YQ (2013): Relationships between PAHs and PCBs, and quantitative source apportionment of PAHs toxicity in sediments from Fenhe reservoir and watershed. Journal of hazardous materials 248249, 89-96

40. USEPA (2004): Risk assessment guidance for superfund, volume 1, human health evaluation manual (part E, Supplemental Guidance for Dermal Risk Assessment). U.S. Environmental Protection Agency, Washington, DC

41. Wang W, Massey Simonich SL, Xue M, Zhao J, Zhang N, Wang R, Cao J, Tao S (2010): Concentrations, sources and spatial distribution of polycyclic aromatic hydrocarbons in soils from Beijing, Tianjin and surrounding areas, North China. Environmental pollution 158, 1245-51

42. Wang X-T, Hu B-P, Cheng H-X, Jia H-H, Zhou Y (2018): Spatial variations, source apportionment and potential ecological risks of polycyclic aromatic hydrocarbons and synthetic musks in river sediments in Shanghai, China. Chemosphere $193,108-117$

43. Wang YB, Liu CW, Kao YH, Jang CS (2015): Characterization and risk assessment of PAH-contaminated river sediment by using advanced multivariate methods. The Science of the total environment 524-525, 63-73

Page $12 / 15$ 
44. Xu J, Zhang Y, Zhou C, Guo C, Wang D, Du P, Luo Y, Wan J, Meng W (2014): Distribution, sources and composition of antibiotics in sediment, overlying water and pore water from Taihu Lake, China. The Science of the total environment 497-498, 267-273

45. Yunker MB MR, Vingarzan R, Mitchell RH, Goyette D, Sylvestre S. (2002): PAHs in the Fraser River basin: a critical appraisal of PAH ratios as indicators of PAH source and composition. Organic Geochemistry 33, 27

46. Zhang Y, Guo CS, Xu J, Tian YZ, Shi GL, Feng YC (2012): Potential source contributions and risk assessment of PAHs in sediments from Taihu Lake, China: comparison of three receptor models. Water Res 46, 3065-73

47. Zhao Z, Jiang Y, Li Q, Cai Y, Yin H, Zhang L, Zhang J (2017): Spatial correlation analysis of polycyclic aromatic hydrocarbons (PAHs) and organochlorine pesticides (OCPs) in sediments between Taihu Lake and its tributary rivers. Ecotoxicology and environmental safety $142,117-128$

48. Zheng B, Wang L, Lei K, Nan B (2016): Distribution and ecological risk assessment of polycyclic aromatic hydrocarbons in water, suspended particulate matter and sediment from Daliao River estuary and the adjacent area, China.

Chemosphere 149, 91-100

\section{Figures}

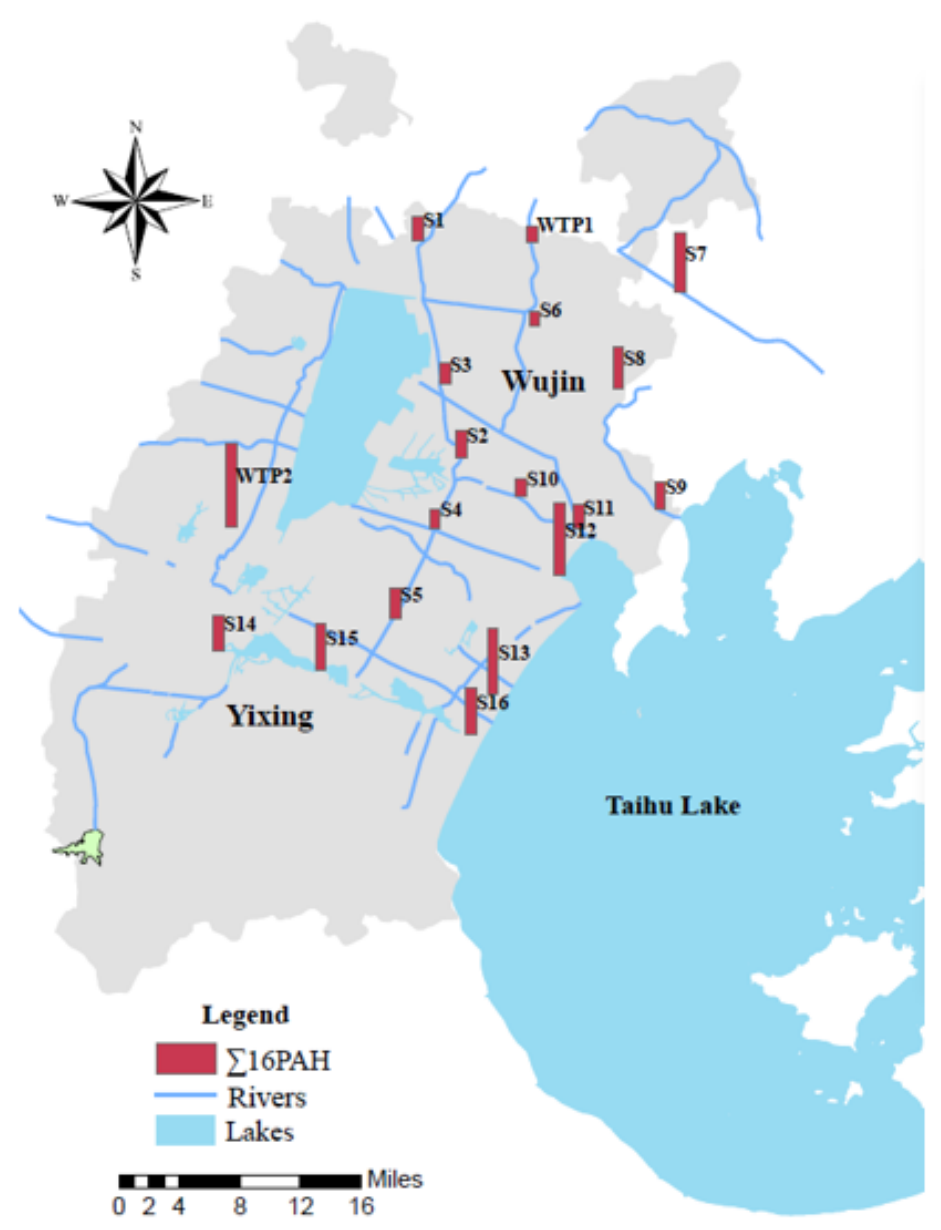

\section{Figure 1}

The total concentration of $16 \mathrm{PAHs}(\mathrm{\Sigma} 16 \mathrm{PAHs})$ in the sample sites 


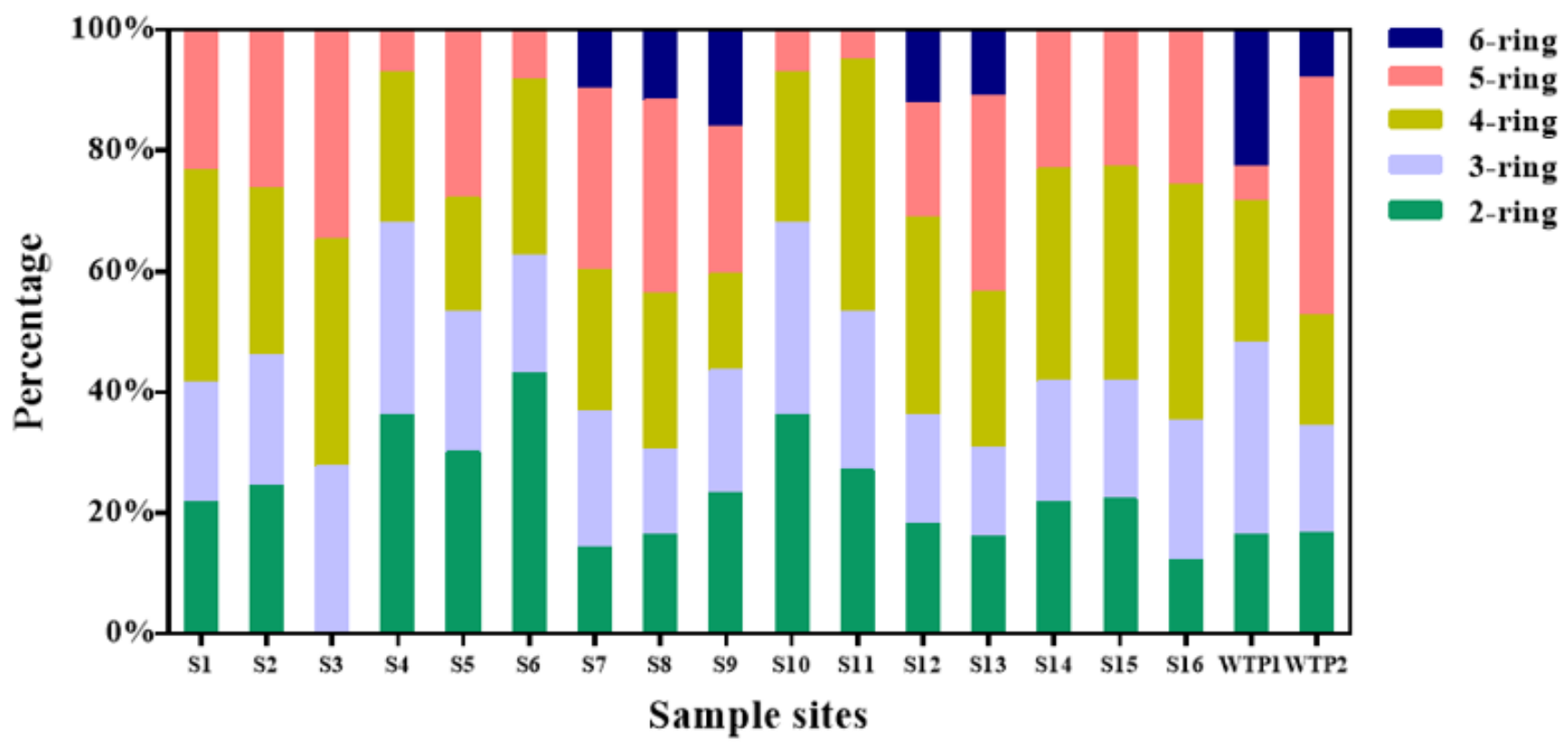

Figure 2

Percentage of different rings in sediment total PAHs
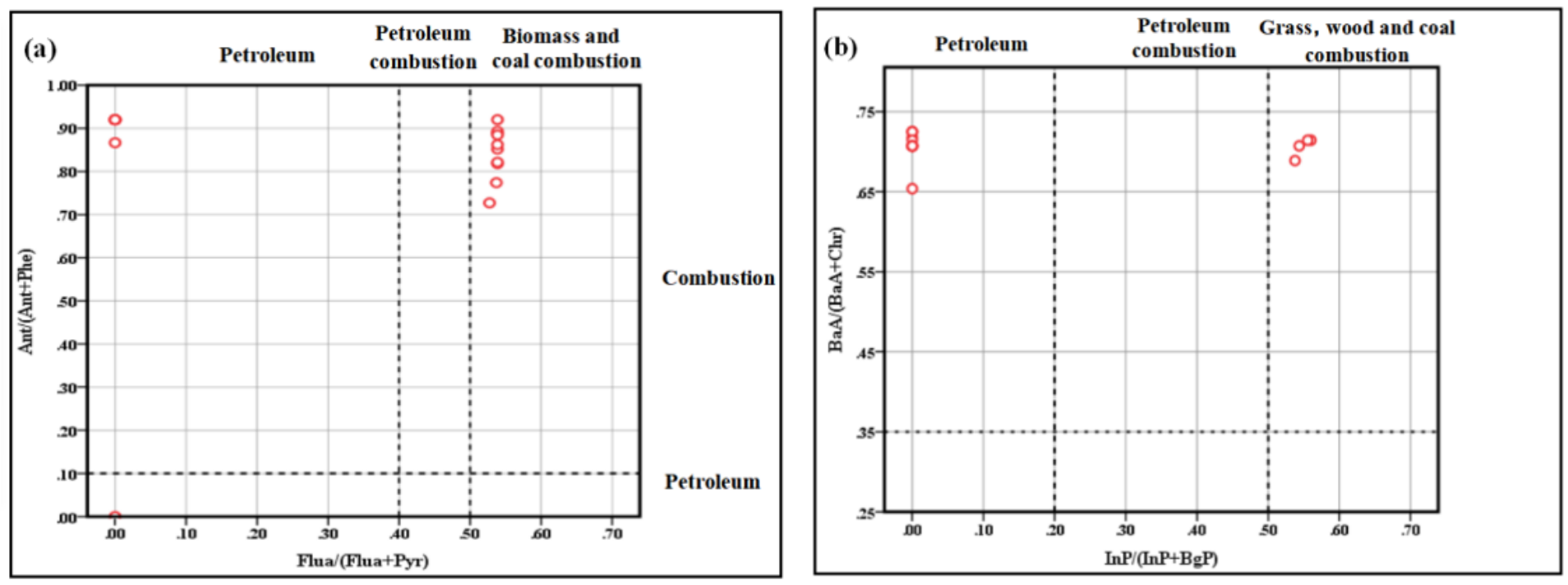

Figure 3

The cross-plot for the ratios of (a) Ant / (Ant + Phe) vs Flua / (Flua +Pyr), (b) BaA / (BaA+Chr) vs InP / (InP + BgP) 


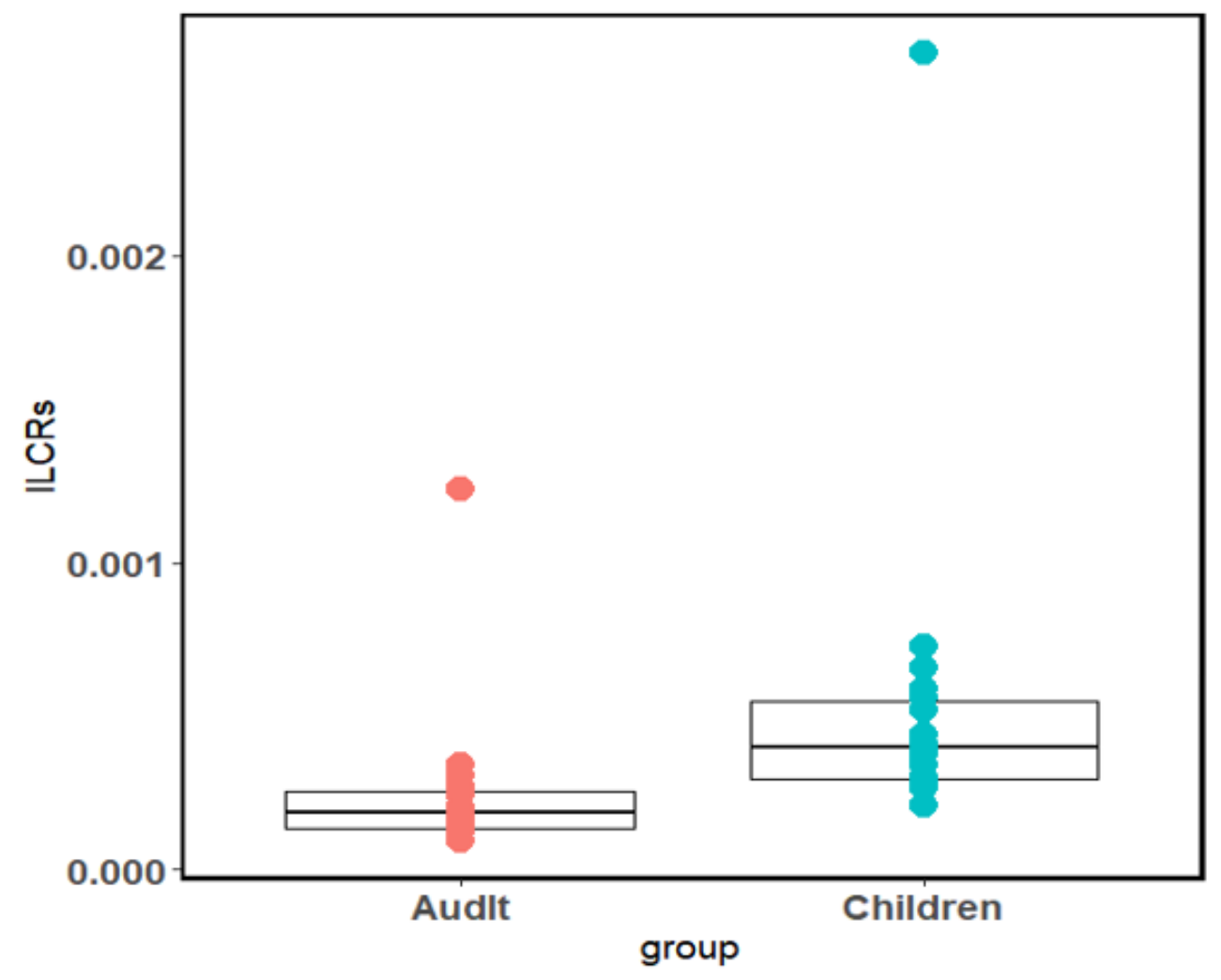

Figure 4

Incremental lifetime cancer risks (ILCRs) for PAHs: ILCRs for children and adults

\section{Supplementary Files}

This is a list of supplementary files associated with this preprint. Click to download.

- supplementaryfile.docx 